\title{
The creation of coastal space - how local ecological knowledge becomes relevant
}

\author{
Jahn Petter Johnsen*, Bjørn Hersoug and Ann-Magnhild Solås
}

\author{
* Correspondence: \\ Jahn.Johnsen@uit.no \\ Norwegian College of Fishery Science, \\ University of Tromsø, The Arctic \\ University of Norway, N-9037 Tromsø, \\ Norway
}

\begin{abstract}
Since the 1990s, substantial efforts have been invested in Local Ecological Knowledge (LEK) research, but LEK has only been applied in western fisheries and resource management to a limited extent. The attempts to link LEK to model-based fish stock assessment seem to have failed largely because the format of LEK does not fit into the models currently in use. However, LEK is still relevant for natural resource management. This article approaches LEK from a different position, not as knowledge about fish stocks but as a constituent in the creation of coastal space as a management object. Through the description of procedures and practices for collection, mapping and authorisation of LEK in Norway, the article illustrates how LEK can potentially become a central element in fisheries and coastal management by using the construction of coastal space as a core management object. As the article will show, the translation of users' experiences into formal knowledge (LEK) about specific activities in certain localities imbues the coastal space with formerly unknown properties and contributes to turning it into a more complex management object. Thus, the article illustrates that LEK becomes relevant for management when it is presented in a format that fits into the frames of reference used in coastal zone management.
\end{abstract}

Keywords: Local ecological knowledge; Fishers' knowledge; Multiple objects; Coastal space

\section{Local knowledge - knowledge about what?}

Our story starts during the winter fishery for North East Arctic cod (Gadus morhua) ${ }^{\mathrm{a}}$ on a fishing ground outside Senja in Northern Norway in 2011 (Figure 1, Area 1), on board a 15 meter long gillnetter with two men fishing on this particular fishing ground for their first time. During participant observation, we could observe and experience how they struggled to learn how to fish in a new area. When a string of nets was hauled, as a newcomer to the ground, the skipper had to decide whether to set again in the same position or start looking for a new place to deploy the gear. Based on the size of the catch, information he had obtained from the old-timers on shore, advice from other skippers fishing in the same area and his own interpretation of the relationship between an unfamiliar bottom, unfamiliar currents and fish behaviour, this was like trial fishing, and he had to discuss with his crew before he made a final decision. The skipper had more than 30 years of fishing experience from the fishing grounds around the Lofoten Islands, where he actually knew the waters intimately (Figure 1, Area 2). In 2007 and 2009, we conducted fieldwork on board this vessel when the

(c) 2014 Johnsen et al.; licensee Springer. This is an open access article distributed under the terms of the Creative Commons Attribution License (http://creativecommons.org/licenses/by/2.0), which permits unrestricted use, distribution, and reproduction in any medium, provided the original work is properly cited. 


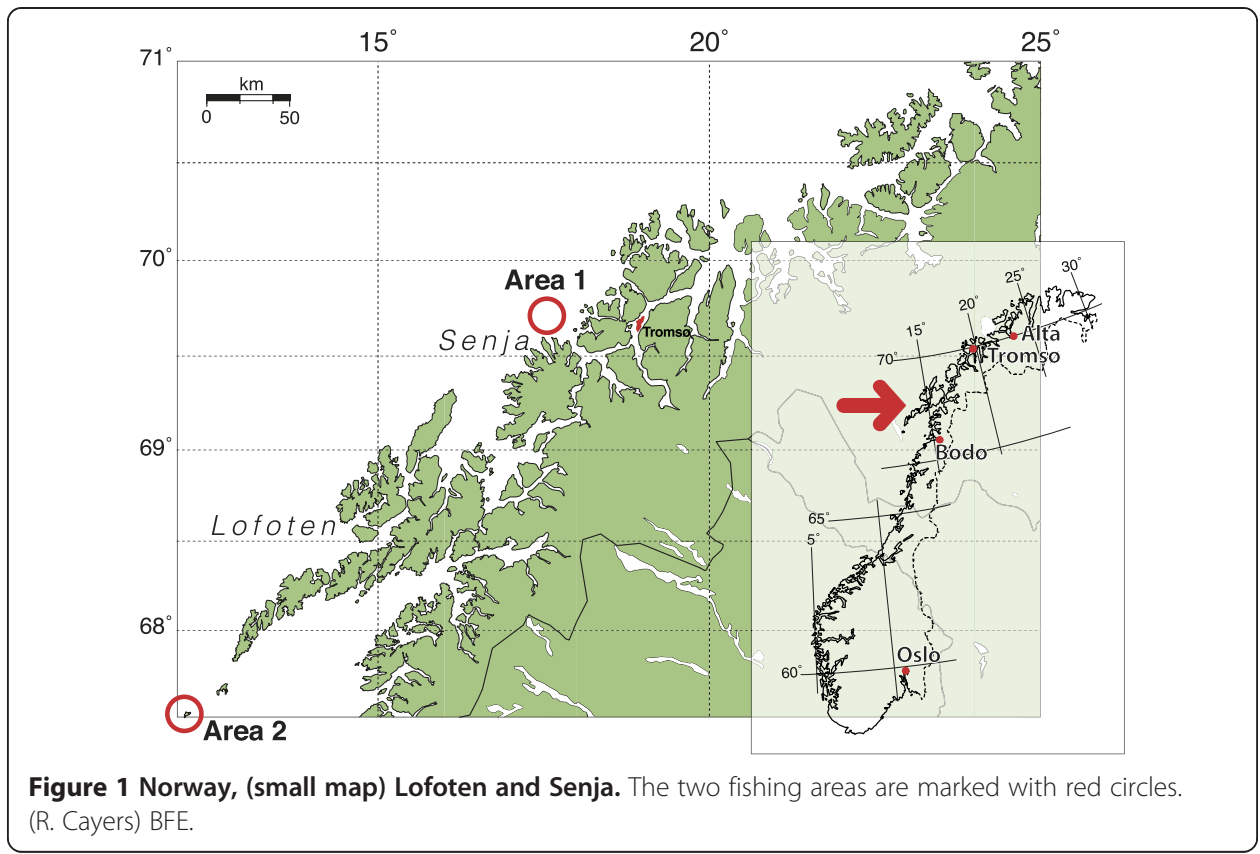

skipper fished in familiar waters. Here, when a string was hauled, he made some short phone calls to other boats and then made a rather quick decision about where to set, and you could be sure that he would obtain a decent catch ${ }^{\mathrm{b}}$. Based on information about fish prices and contacts with different processing plants, in 2011, he decided to try a new area outside Senja about 180 nautical miles to the Northeast (Figure 1, Area 1). This was a fishing ground entirely unknown to him. In 2011 we followed him to the new fishing ground and we also spent a couple of days on board with him in 2013. On this new fishing ground, the situation was quite different. In 2011, we soon realised that we could actually catch nothing, even if the boats next to us hauled nets full of fish. Second, and quite different from the situation in Lofoten, the fishers did not sound for the fish, but used the echo sounder to find the right seabed profile. In Lofoten, they set when they find fish on the echo sounder, while outside Senja the fishers set on experience based on where the fish usually come ${ }^{c}$. If you are on the right spot, you will catch fish when they come, if you are on the wrong spot you may catch nothing.

The skipper's practical behaviour was different in the two areas and resulted in different outcomes. These differences illustrate the relationship between resource harvesters and the environment they live in, that is, between fishers, the area they fish in and the fish behaviour in that particular area. This relationship, known as Local Ecological Knowledge (LEK) or Fishers' Ecological Knowledge (FEK), is well described by a number of scientists (Berkes 2007; Davis and Wagner 2003; Maurstad 2000; McGoodwin 1990; Murray et al. 2006; Neis et al. 1999).

This LEK/FEK is based on individual and common experiences and perceptions of relationships between biotic components, like fish and plankton, and abiotic components like currents, wind, temperatures and the area they operate in. All together, these elements form a body of practical knowledge about certain ecological relationships. Our perspective differs from Berkes's (2007) holistic approach, as we do not see this knowledge (LEK/FEK) as total or holistic knowledge about a particular or bounded ecosystem but 
rather as practical experience derived from particular relationships in a certain environment (Aswani 2011; Valdés-Pizzini and García-Quijano 2009), often formulated and presented on the backdrop of or in relation to modern science that to some extent has provided the users with their language and their concepts for talking about their experiences. Thus, LEK/FEK research can be seen as a process of coding, standardising and refining LEK/FEK into a scientifically refined fishing knowledge or, what Holm (2003) called FEK* (Davis and Wagner 2003; Murray et al. 2008) ${ }^{\mathrm{d}}$.

The interest in LEK grew out of the hardships that fisher folks around the world felt in the wake of development of western fisheries governance systems. LEK research raised an extensive international debate about the relevance and use of local fishing knowledge in fisheries governance in the 1980s (McGoodwin 1990). Throughout the 1970s and 1980s it became clear that the modern (Western) fisheries overexploited the resources and that governance had largely failed (Holm and Nielsen 2007). In particular, the collapse of the cod fishery in Canada at the beginning of the 1990s contributed to scepticism toward scientific fisheries governance based on historical catch statistics and numerical models. It was claimed that these resource crises were also the result of a knowledge crisis (Finlayson 1994), which in turn contributed to a resurgence of research associated with LEK (Berkes 2007; Degnbol 2003:32; Garcia and Charles 2007; Holm 2003; Holm and Nielsen 2007; Johannes et al. 2000; Neis and Felt 2000). In Norway, Maurstad and Sundet (1998) did some ground-breaking work when they, on the basis of interviews with fishers, indicated that fishers had very precise knowledge about local cod stocks. However, despite the documentation of LEK and the attempts to use it (Bjørkan 2011), applying LEK in modern fisheries governance has "remained hypothetical" for a long time (Davis and Wagner 2003:475). Second, as Holm (2003) points out, the reason why LEK is not used more can also be related to how LEK is translated and transformed from practical knowledge into scientific knowledge. This is what Holm calls FEK $^{*}$, the selected and refined information that can be relevant for modern fisheries science, produced and translated through specific procedures. According to Holm (2003), LEK research has partially established that fishers are accepted as holders of knowledge fragments that, under certain conditions, can be relevant for fisheries science. At least in a North Atlantic context, with a strong institutionalised system for fisheries science and advice for single stock management, LEK research has been about sorting and dis-embedding the fisher's knowledge from the local practical and cultural context and to re-embed this knowledge into fisheries science. So far, as several projects have illustrated (Maurstad and Sundet 1998; Murray et al. 2008), this dis-embedding is quite well established as scientific practice, whereas the re-embedding of even the relevant FEK ${ }^{*}$ has proved to be difficult, as Bjørkan (2011) has demonstrated. The problem may be related both to scale, to the institutionalised model for stock assessment and advice and to the governance object. Finally, the managers' perspective on the relationship between science and governance will also be of importance. If fisheries governance relies entirely upon authorised scientific knowledge, LEK will not meet the standards, not even in the form of FEK* (Valdés-Pizzini and García-Quijano 2009; Valdés-Pizzini et al. 2012; Thornton and Scheer 2012). According to this view, application of LEK implies a need for an institutional reform or a different approach to what kind of object we attempt to govern.

Due to the fact that interest in LEK grew out of resource crises, the attempts to apply LEK have been directed toward single fish stock assessment and management. LEK has 
been seen as knowledge that would expand the possibilities for better stock assessment, clarify stock structures and result in a more targeted management (Maurstad 2000; Maurstad and Sundet 1998; Neis and Felt 2000). Taking into consideration that the North Atlantic fish stock management is model-based and requires a specific data format (Bjørkan 2011; Murray et al. 2008), this ambition has been rather unrealistic. However, despite this problem, our argument is not that LEK research has been wrong or misplaced, but that the attempts to apply LEK may have been directed toward the wrong governance object. From our point of view, and as others have pointed out, LEK is not about providing a better empirical basis for theoretical fish stock modelling but about a quite different governance object, namely coastal space (Valdés-Pizzini and García-Quijano 2009).

Through a description of what comprises LEK in the Norwegian context, the present article illustrates how LEK contributes to the creation of marine space as a governable object. Our focus is on the authorised procedures for collection and stabilisation of LEK. The article outlines how LEK is stabilised as knowledge and applied in coastal planning and ends with a discussion of some of the consequences of this application. The article is an illustration of how the concept of an ecosystem-based approach to coastal governance is constructed and filled with meanings and properties. In this article, we will show how LEK becomes a relevant element in coastal governance. Next, the article will also illustrate the thresholds that LEK supporters will have to transgress in order to make LEK accountable. Finally, as Degnbol (2003) demonstrated, it will become apparent that LEK is knowledge about conditions and resources in specific areas and cannot be seen as knowledge about the scientifically modelled and constructed fish stocks that are used in fish stock assessment and fishing quota management.

We start out with a presentation of our theoretical perspective on objects and knowledge. After a brief presentation of our methodological approach, we turn to a description of the three phases of constituting objects and knowledge. Next we present the outcomes of the process, in particular in the form of maps, and point to the importance of mapping when building objects and knowledge. Finally, in the concluding section, we discuss the implications of our findings for fishers, managers and future LEK research.

\section{The constitution of coastal space through mapping}

In their description of the attempts to make fisheries governance possible, Johnsen et al. (2009a) used an actor-network theory (ANT) approach to describe how fish becomes a manageable object through scientific and administrative practices. These practices create "fish" as an object of knowledge that can be calculated, modelled and simulated for governance purposes. As the actor-network term implies, ANT is not about individuals but about action that takes place through relationships or networks. The ANT approach is useful for exploring how specific objects are created or stabilised through a wide range of practices and actions that take place in relationships. In ANT, knowledge is always seen as being about an object, and these objects do not exist independently of each other. This implies that, when talk and experiences from fishing through a specific procedure can be transformed into LEK, a specific knowledge object is created in this process. Callon (1986) described the process we refer to as the process of translation. The actual translation is "all the negotiations, power games, statements and actions that an actor or force performs to gain power, authority and legitimacy to speak or act on behalf of others" 
(Callon and Latour 1981:279). Thus, the translation process is about stabilising the relations that constitute the multiple objects in a way that makes the object(s) durable. Holm (2003) used the concept of translation to describe how FEK is turned into FEK $*$, the purified, "scientific" version of FEK. The concept of translation in ANT explains how heterogeneous and material objects are woven together to form entireties (Latour 2005) or what Mol (2002) called multiple objects. Consequently, the multiple objects do not have a clear and specific ontology but can be described as a network of relationships between many different types of actors, people, organisations, natural elements, images and ideas, all playing different roles. In her book, The Body Multiple: Ontology in Medical Practice, Mol (2002) studied the process of how the multiplicity of the disease atherosclerosis becomes translated and coordinated into a treatable object within the framework of a modern hospital. The process is quite similar to how a governance object can be created and constituted inside a given framework.

Inspired by Mol, we will describe a similar process that uses specific procedures to apply LEK to practical governance. Following Latour (2005), we will make an account of the components of LEK and the instruments that are mobilized and deployed to stabilize it as applicable knowledge for governance purposes. The process takes place in three partly overlapping phases: 1) a coordination phase, during which a common language, common categories and concepts are established; 2) a phase during which the roles, responsibilities, indicators, and solutions are defined; and 3) a phase during which the elements from the first two are bound together into objects that are both existing side by side and mutually included in each other, for example, both the space and the properties will exist side by side, but the space will also be defined by the properties, and the properties are defined as spatial. This variety will be coordinated inside a specific framing process that makes it possible to manage the space with the included properties (see Table 1).

A key activity in the translation processes that we describe is the work of the map. Mapping practices and technology represent the coordinating framework for the constitution of coastal space as a governance object. In Latour's (2005) terms, mapping is about the inscription of LEK into a stabilizing device, the geographical map. When various coastal activities are mapped, these activities become firmly anchored to a specific coastal space and lay the basis for defining the space's properties. Mapping produces reality, constructs knowledge and exercises power (Crampton and Krygier 2005). However, the maps of marine areas are not fixed objects. The Norwegian maps of the coastal zone, either in terms of sector bodies' national maps or municipal land use maps are continuously updated with new information and new knowledge is continuously constructed. Whereas the maps initially contained only geographic information and shipping lanes, now information about fishing grounds, spawning areas, fish farms, the flora and fauna, cultural heritage (shipwrecks), proposed marine protected areas, etc., are added. New interests arise constantly, demanding that their activities appear on maps, such as sites for wind turbines in the sea or areas that are suitable for landfill mining.

Consequently, while mapping on the one hand is a stabilising practice, maps are also dynamic, even if they fix some activities and properties of the space at a certain point in a way that makes these properties replicable. Mapping and cartography is no longer a discipline for the elites; it has opened up to people able to handle simple computer programs (Crampton and Krygier 2005). Despite this dynamic, in marine and coastal governance, maps still represent a form of objective knowledge, which is difficult to 
Table 1 Overview of the phases for creation of a management object (after Mol 2002)

\begin{tabular}{|c|c|c|}
\hline Phase & Actions & Outputs \\
\hline \multirow{2}{*}{$\begin{array}{l}\text { Coordination and } \\
\text { definition of relevant } \\
\text { actors and contributors }\end{array}$} & \multirow{2}{*}{$\begin{array}{l}\text { Data collection methods, coordination, } \\
\text { calibration and conceptualisation, } \\
\text { definition of the objects }\end{array}$} & $\begin{array}{l}\text { Establishment of a common language, } \\
\text { categories, and objects. }\end{array}$ \\
\hline & & $\begin{array}{l}\text { Consensus about the object and how it } \\
\text { can be categorised (interviews). }\end{array}$ \\
\hline $\begin{array}{l}\text { Distribution of power } \\
\text { and responsibilities }\end{array}$ & $\begin{array}{l}\text { Defining and selecting problems, } \\
\text { solutions and indicators, establishing } \\
\text { relationships and allocating } \\
\text { responsibilities. }\end{array}$ & $\begin{array}{l}\text { Actors with defined roles and } \\
\text { responsibilities in relation to the } \\
\text { management object, defined space for } \\
\text { each player, choice of instruments } \\
\text { (maps, quality assurance and validation) }\end{array}$ \\
\hline \multirow[t]{3}{*}{$\begin{array}{l}\text { Inclusion, stabilising } \\
\text { the network }\end{array}$} & $\begin{array}{l}\text { Knowledge definition and authorization, } \\
\text { inclusion of actors, exclusion of } \\
\text { non-participants. }\end{array}$ & $\begin{array}{l}\text { The knowledge object is constituted and } \\
\text { stabilised through the published maps. }\end{array}$ \\
\hline & \multirow[t]{2}{*}{$\begin{array}{l}\text { Evaluation and modification of instruments, } \\
\text { production of official maps. }\end{array}$} & $\begin{array}{l}\text { Space, spatial properties, spatial } \\
\text { representation and practices will } \\
\text { exist side by side. }\end{array}$ \\
\hline & & $\begin{array}{l}\text { The space contains the properties and } \\
\text { the practices, while the properties and } \\
\text { practices get a spatial dimension. }\end{array}$ \\
\hline
\end{tabular}

challenge if other users are not able to present the same type of information or specific piece information in the same form. Smith (2011) and Smith and Brennan (2012) show, with examples from Scotland, how mapping of marine areas is not based on objective knowledge but on indicators developed through judgement. For example, the importance of the various fishing areas is assessed on the basis of fishing efforts taking place in the various blocks that a space is divided into. However, the fleet's location will differ from one year to another, and the map makers must make decisions on whether fishing efforts take place in one block or the other. The selected indicator of fishing effort; $\mathrm{kwD}$ (kilowatt $\times$ Days) is not a constant. It is influenced by several factors, including wind and weather, boat and engine age, fishing pattern, and the price of fish and fuel. Such flexible indicators appear as objective and fixed when they are used to identify an activity that is inscribed into a map. Therefore, considerable power is related to the ability to produce relevant data and information for the actual mapping exercise.

St. Martin and Hall-Arber (2008) have demonstrated, with reference to fishing off the northeast coast of the United States, how mapping of activity and GIS tools can be used to explore who fishes where and what fishing grounds the various fishing communities are most dependent on. Through a combination of interviews and plots on a map that are later calibrated and assembled into a database and processed into digital maps, they show which fishing grounds are important for different communities. St. Martin and Hall-Arber (ibid) illustrate that the sea consists of more than catch areas and zones; they also map relations between specific fishing grounds and communities on the shore. In addition to their economic importance, these grounds will have meaning and cultural significance in local communities on shore. A similar approach has been used to map and interpret Sami fishing space in northern Norway (Brattland and Nilsen 2011). Thus, in both cases, fishers' use and knowledge become relevant components in the construction of coastal space. Before we follow our Mol-inspired scheme and take a closer look into how fishing knowledge is identified, constituted and applied, we will briefly present the methods we have used. 


\section{Method}

This article is based on extensive fieldwork, participant observation on board a fishing vessel under the arctic cod fisheries in 2007, 2009, 2011 and 2013 in two different areas, interviews with a number of key stakeholders and a review of public documents. With regard to obtaining insight into the data collection procedures used to collect fishers' knowledge, we have carried out a thorough analysis of the manuals for data collection from the Directorate of Fisheries (DoF) to be able to describe the procedure and the processes (Directorate of Fisheries 2008, 2010a, b). In addition, we have used interviews with the data collectors, and, finally, we have also drawn upon experiences from the use of the same type of methodology in studies of the fisheries in Labrador in 2003 (Johnsen et al. 2009b; Murray et al. 2006). Not least, we have tried to trace the mapping process behind the maps published by the DoF and the Institute of Marine Research (IMR).

\section{Coordination - defining knowledge and framework}

The western governance models institutionalise a division of labour between a positivistic and reductionist science and pure politics, where neutral and unbiased science informs political decisions. In practice, however, science is not unbiased and neutral, and the boundary between science and politics is not easily drawn. Thus, a massive amount of boundary work has been undertaken to establish such a boundary (Berkes 2007; Holm 2003; Nielsen 2008). In the positivist and reductionist science ideal that has dominated, users' knowledge has been regarded as non-scientific and has found no room in what we can call the fisheries governance network.

The position of fisheries biology and biologists in the governance system is institutionalised through a network of science collaboration in the International Council of the Exploration of the Sea (ICES) and a network of national research institutes, rigged with resources and infrastructure for research and for scientific advice. This network, with ICES as its hub, holds the resources and the capacity to authorise what kind of science and knowledge count in fisheries governance (Bjørkan 2011; Johnsen 2004; Nielsen 2008; Rozwadowski 2002). Thus, to become knowledge that counts in giving advice, LEK has to be authorised through this fisheries biology network, serving as an obligatory passage point for the flow of information, translation and problem definition in the fisheries.

As previously mentioned, in the Western context, the interest for fishers' ecological knowledge came as a reaction to the obvious failures of single stock management in Canada and Norway in the 1990s. The collapses of Canadian and Norwegian cod stocks resulted in a public rejection of the epistemic authority of the fisheries scientists (Holm 2003), and a group of academics turned towards the fishers in search for more reliable knowledge to be used for fisheries governance (Berkes 2007; Davis and Wagner 2003; Degnbol 2003; Murray et al. 2008; Neis et al. 1999). This growth in interest for local knowledge can, according to Berkes (2007), be seen as a more general objection to the globalisation of western science and western governance systems relying entirely on scientific and administrative expertise. To claim that users' knowledge is relevant and valid, that users are also experts, raised the stakes for scientists and science-based management. An acceptance of LEK as relevant for fisheries governance may shift power from scientific institutions to users and may represent an empowerment of these users, which in turn may lead to a shift in the division of labour between managers and users, 
or as expressed by Davis and Wagner (2003: 465): "to provide peoples and communities with a much greater capacity to self-direct and self-manage, thereby empowering them through provision of control over core factors in their lives and livelihoods."

In this climate, where expertise and epistemic superiority of the scientist were challenged, LEK researchers argued that the resource crisis was a knowledge crisis and that the knowledge gap in the governance system could be filled with an identifiable body of knowledge originating from the relationship between nature and those who harvest (McGoodwin 1990; Neis and Felt 2000; Neis et al. 1999). As mentioned, this never became a success: LEK did not become the answer to the failures in resource management, and the users' knowledge did not count in formal fisheries governance (Bjørkan 2011). However, the spatial turn in resource governance, with more focus on ecosystems and spatial planning, has recently contributed to change this situation.

\section{User participation in Norwegian fisheries governance}

In Norway, inclusion of fishers in fisheries governance has a long tradition. As described by Jentoft and Kristoffersen (1989), a co-management system mandated by law in 1897 and controlled by the fishers themselves has been used to resolve conflicts over space between fishers using different gears in the important arctic cod fishery in Lofoten in Northern Norway. This system established the rules of order that increased the effectiveness of the fishery and ensured that all fishers had a chance to catch (Holm et al. 2000). Outside of Senja, similar co-management arrangements have been in use (Søreng 2006), not only dividing the sea space between different gear groups but also allocating specific positions for fixed gear to different vessels. As we could hear on the VHF radio, this system makes it necessary to negotiate if you want to set your nets in the position of another fishing vessel. Some boats even left a buoy in their spot when they hauled up for the weekend to mark their right to use this particular spot.

Moreover, since the 1930s, the Norwegian Fishermen's Association (NFA) has been formally and informally consulted in most fisheries governance issues. The NFA was established in 1926 and was until 1988, when the Norwegian Coastal Fishermen's Association (NCFA) was formed, the only national professional organisation for Norwegian fishers. These two organisations are national with local branches all along the coast (Hersoug 2005; Holm 1995). Today both organisations collaborate with the fisheries authorities, and they wield considerable political power, especially considering their low membership numbers. For example, all the long-term allocation keys for quota allocations in the Norwegian fisheries are based on advice from the NFA (Hersoug 2005). In addition, the pioneers of Norwegian fisheries research collaborated closely with fishers, although with a clear division of labour and in different roles (Schwach 2000).

However, in spite of this historical collaboration and fishers' influence in governance, the fishers' ecological knowledge was not regarded as relevant for stock assessment. Although fisheries scientists had already found indications of differences between coastal and oceanic components of the Northeast Arctic cod stock in the 1930s (Rollefsen 1933), the stock has been managed as one big stock. In the 1990s, a social scientist and a fisheries biologist carried out interviews among 70 active fishers in Finnmark county in Norway (Maurstad 2000, 2002; Maurstad and Sundet 1998). Their study was not directed toward identifying ecological knowledge as a body of knowledge but toward using the fishers' experience to identify local cod populations and spawning grounds. Based on their interviews, 
they identified 34 local spawning grounds that could indicate the existence of several local cod populations. However, after ethical considerations, they decided not to publish more of the results displaying good fishing grounds in the area (Maurstad 2002). The ambition of contributing to better stock assessment for local stocks with the mapping were not fulfilled in the short term (Maurstad 2000), but the project probably contributed to bringing the existence of local cod populations back on the fisheries management agenda. Moreover, the project represented a link to an emerging field of research. Even if the knowledge was not directly applicable, it was seen as an indication that formal science did not provide all answers. During the following years, more resources were allocated to research on local fish populations, and today the costal cod is seen as a stock component that has to be protected, with important implications for the governance system (ICES 2010).

\section{Attempts to register LEK in Norway}

Although Maurstad and Sundet's research was the first scientific project in Norway influenced by LEK research, they did not entirely start from scratch. The Directorate of Fisheries (DoF), which is the technical and administrative body responsible for fisheries and coastal governance in Norway under the Ministry of Fisheries and Coastal Affairs, was involved in its first survey projects to map fishing activity along the coast early in the 1980s (Directorate of Fisheries 2008). In the 1980s, aquaculture development increased the conflict potential between fishing and aquaculture, and coastal zone planning became an issue. Subsequently, DoF saw the need to identify important fishing grounds and spawning and nursery areas for fish to avoid locating aquaculture farms in such areas.

In 2003, DoF created a GIS database for key resources and fishing activities in the coastal zone. Parallel with this work, a process of mapping biological diversity in Norway started, initiated as a consequence of the Norwegian obligations under international agreements on biodiversity (Directorate for Nature Management 2007). The Institute for Marine Research (IMR) and DoF were assigned responsibility for collecting data for the marine sector in two independent projects. While IMR collects data through research cruises, DoF is using interviews as their main method. Manuals have been made to ensure that the interview data collection is conducted systematically and consistently in order to produce valid and reliable data. The DoF manuals also emphasize why this work is important:

As a result of the decline in the number of commercial fishers, important local knowledge of fisheries is in the process of disappearing in some areas along the coast. In areas that are inadequately surveyed it is therefore an urgent need to collect these data. This knowledge is important to know how the coastal areas can best be managed. (Directorate of Fisheries 2010a: 3)

Thus, DoF recognizes fishing knowledge as valid and valuable for the governance system and takes the responsibility of incorporating it into the governance system.

\section{Distribution - responsibilities and practical work}

The data collection process described in the manual (Directorate of Fisheries 2010a; Directorate of Fisheries 2010b) is detailed and quite similar to the process described in LEK research (Maurstad and Sundet 1998; Murray et al. 2006, 2008; Johnsen et al. 2009b) One of the measures proposed in the guidelines is to conduct interviews individually 
in order to avoid that informants influence each other. However, due to the transparency in the local communities, this is not always possible. In many cases, several fishers meet, even if the appointment has been made with one fisher alone. The interviews are conducted on the basis of a standardised guide: informants complete a questionnaire and are asked to plot fishing areas and key resource areas on a nautical chart. Moreover, they are interviewed about what species are fished, what types of gear are used, and during which seasons they fish in different areas; finally they are asked to give an estimate of the number of vessels that fished in a particular area. Based on this information, the interviewer records whether a fishing ground is of local, regional or national significance. Differently coloured pens are used to plot the information, with a colour code for each layer of information. The detailed procedure shall standardise and ensure the quality, reliability and validity of the collected data. The mapped information of the resource areas include spawning areas, important nursery areas for juveniles and small fish, important feeding grounds for larger fish and key migration routes. Areas with sponges, corals and shells are also registered.

In addition to the resource and fishing areas, the fishers are asked to mark net pen sites for fish storage and to indicate how long ago they were last used. They are also asked how many boats made use of the site and to indicate the importance of the storage area on a four-point scale from "very important" to "unimportant". Fishing grounds have so far not been ranked in the same way (Directorate of Fisheries 2010a). The interview manual states that, if the different fishers give different information about an area, interviews with new informants should be undertaken until preponderance of evidence for one or some of the answers has been achieved (Directorate of Fisheries 2010b). This requires the availability of a certain minimum number of informants within an area. The completed maps are often presented at a meeting with local fishers to gather feedback on the data before further processing. The information from the interviews and the charts is transferred to a GIS database. DoF has given priority to the largest and most important fishing grounds; thus less important grounds may have been left out. DoF roughly assesses how much information is appropriately registered. The mapping process implies that procedures for the users' contribution have now been formally created; although it is DoF that works as the translator of the fisher's knowledge. Through the procedures, a system is also established that coordinates sampling and standardizes and formats the gathered information. As an illustration of the procedures, the process used in the Alta fjord in Finnmark (Figure 1), can serve as an example.

\section{Inclusion: from "subjective" sketches to authorised maps}

Before DoF started its survey in the Alta fjord, a start-up message was sent to the municipality and to the local branch of the NFA ${ }^{\mathrm{f}}$. The work started in November 2005, and, at that time, the DoF guidelines were quite different from the ones that exist today. There were, for example, no recommendations about single interviews. The survey was conducted during a joint meeting with four fishers participating. The four fishers were selected by the DoF staff based on a desire to have a representation from different age groups, experience, various fisheries and different gears. The DoF representatives acted as facilitators and secretaries while the fishers discussed and developed maps. This procedure would not be accepted according to the guidelines used for mapping today ${ }^{\mathrm{g}}$. 
The information from the meeting was transferred to a new map at the regional DoF office. In 2007, a quality assurance meeting took place with the goal of reviewing the work; both the new map and the original map prepared by the fishers were presented to the fishers for approval. At this meeting, four fishers were present also, but only one of them had been involved in the making of the original draft map. The replacement of the participants was part of the validation process and quality assurance.

After the meetings, the digitalization of the work started. The task was conducted by the DoF employee responsible for the survey in Finnmark. The challenge was to transfer the information from the analogue chart to the digital chart. Mapping the fishing grounds for active gear was reasonably straightforward since the main fishing activity was shrimp trawling below $200 \mathrm{~m}$. Thus, the 200-meter depth contour could be followed. Spawning grounds for cod were, according to IMR, generally limited by the 20-meter depth contours toward the land (Directorate of Fisheries 2008). The challenge was to find depths and points in the charts that were consistent with the areas and contours that the fishers had drawn. According to DoF's staff, the digitized charts from Alta deviated little from the plots made by the fishers.

Since then DoF has developed a system for online publishing. Today it is standard procedure to publish maps online on the DoF webpage as a GIS application under the heading "Map tools". As a result, everybody can access the information in the form of maps that allow for different layers of information to be added. The different information layers consist of digitized data, collected from various sources. They include the DoF interview-based data, IMR data from research cruises, data from DoF on aquaculture sites and other public data, such as protected areas and fairways. Figure 2 shows the map tool on DoF's webpage. In the figure, four layers for Alta based on information from fishers are displayed: fishing grounds for active and passive gear, spawning grounds and aquaculture localities.

The DoF registering is vulnerable to the fishers' political agendas (Palmer and Wadley 2007). For example, if fishers are opposed to plans for using an area for aquaculture, they might have an interest in categorizing that area as a spawning ground to avoid aquaculture

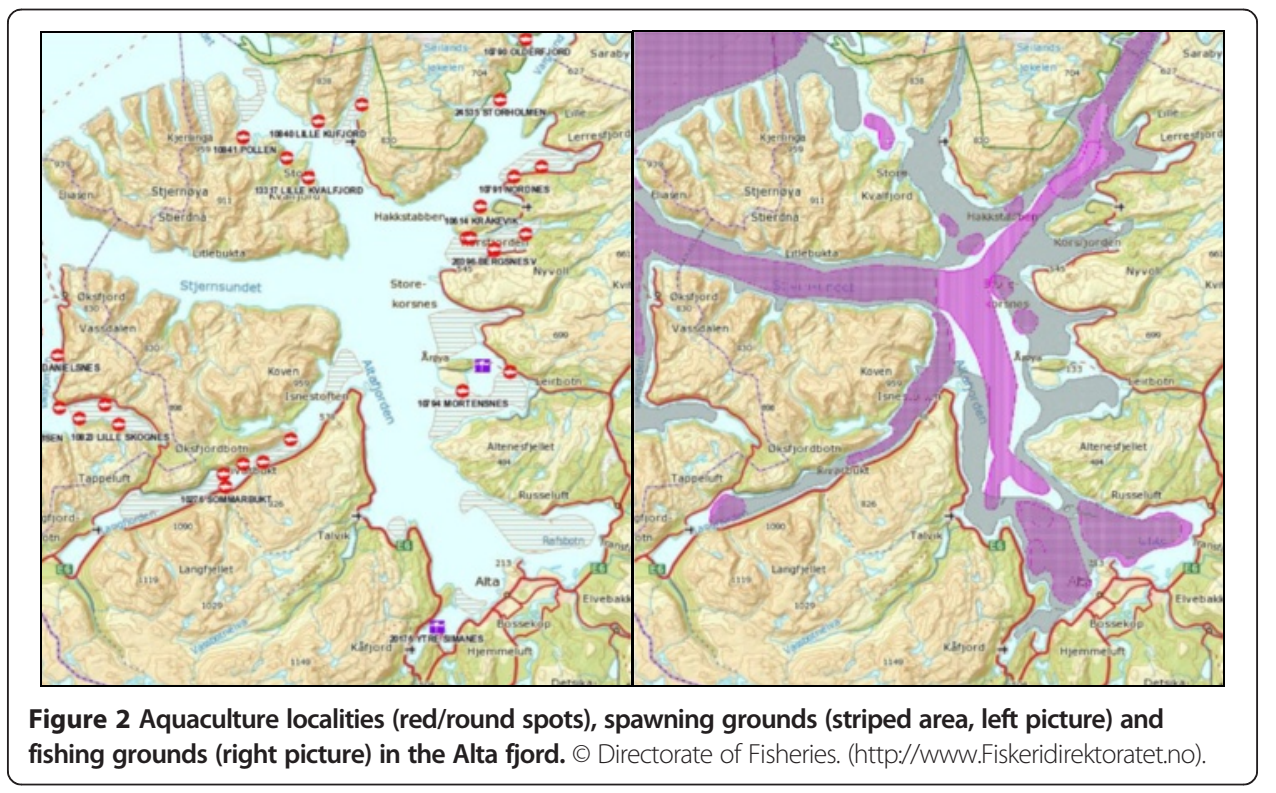


farms there. In such cases, DoF's own verification of the information might not be good enough and regarded as legitimate, because others may claim that the information is neither neutral nor reliable.

The scientific surveys conducted by IMR are independent of the DoF process. During cruises where fish eggs are sampled, IMR's research vessels map spawning grounds for cod along the Norwegian coast. This is a costly and time-consuming task. Troms (the county south of Finnmark) was surveyed in 2009-2011, and the plan was to survey Finnmark in 2012, but the work has not yet started. In open fjords, eggs can be spread all over the fjord, while threshold fjords have clearer retention zones where eggs are held back. The method used in the open fjords combines egg sampling with oceanographic modelling of ocean currents to calculate the size of the spawning grounds. From the development stage of the eggs, the time for spawning can be estimated, and the current models will indicate the spawning ground (Espeland et al. 2010). Figure 3 shows a section of a fishing map from Kvænangen in Troms ${ }^{\mathrm{h}}$, comparing the results from the DoF with the results from IMR. The information is not directly comparable as the IMR maps only show spawning grounds for cod, while DoF maps all species, but, as we see, the results obtained by DoF and IMR closely correspond with each other. The figure suggests that the fishers' knowledge in this case seems to correspond with the results obtained by IMR. The LEK must therefore be said to be credible in this case (Spawning is marked as beige zones with horizontal lines).

The deviation between the two maps in Figure 3 also reflects that IMR's model covers the whole area where the eggs potentially could have been spawned as well as retention zones for eggs and larvae, while the fishers report the positions where they have made observations of mature and spawning fish. Thus, IMR's surveys will usually extend the spawning areas identified by the fishers.

These results are also consistent with studies from the Skagerrak area in southern Norway, where similar explorations have taken place. Knutsen et al. (2010) used a GIS tool to integrate fishing and research knowledge into a digital map. They found that information

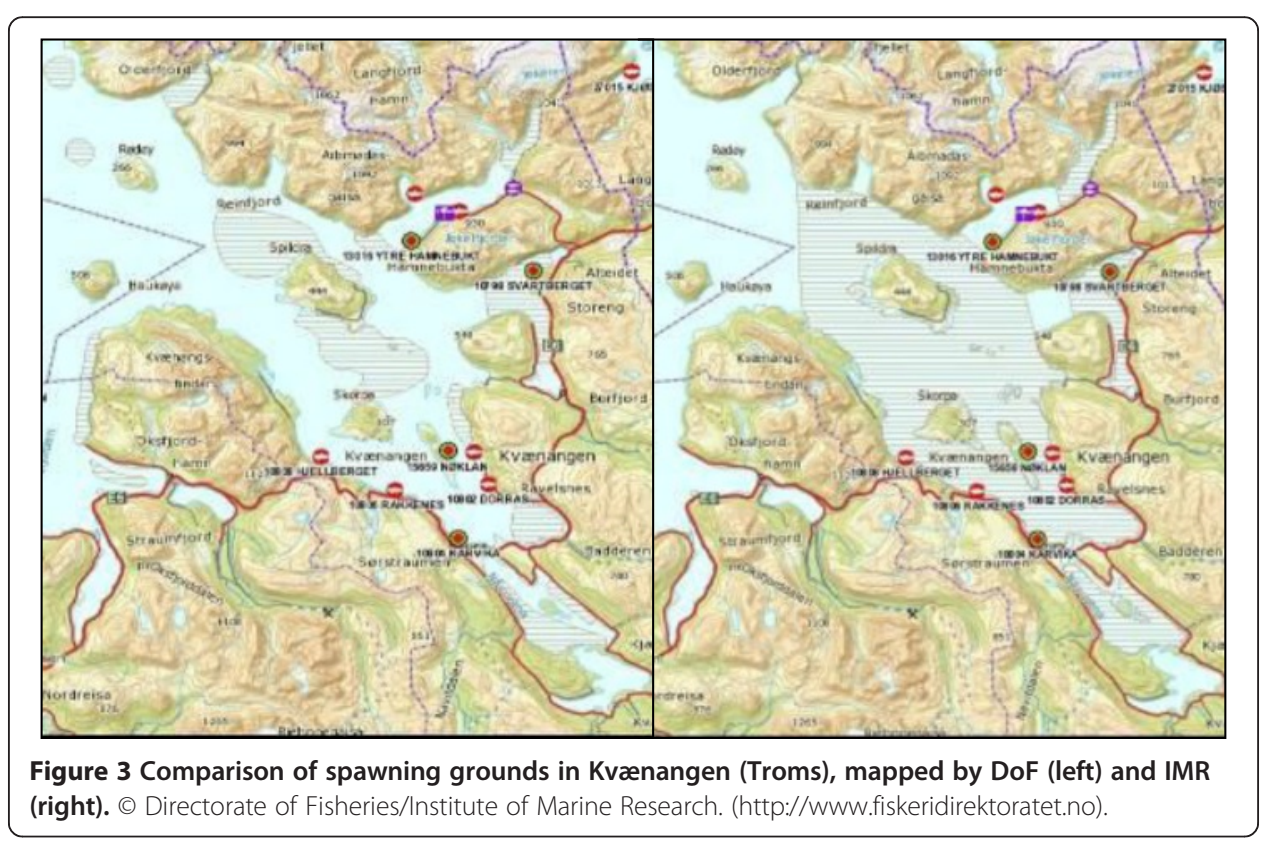


about spawning grounds from fishers was reliable, and that scientific sampling only contributed to marginal adjustments of the areas reported by the fishers.

The translation and stabilisation of fishers' knowledge - from secret meids to mapped objects The processes we have described above have occurred during the last 10-15 years. As late as in the late 1990s, the dominating view was that good fishing grounds (meids) ${ }^{\mathrm{i}}$ were secrets the fishers kept for themselves (Maurstad 1997). Good meids would be inherited from one generation to another; knowledge about meids represented a comparative advantage for the fisher. Therefore, to publish the fishers' knowledge would be to give away "trade secrets" to competing fishers, whether professional or recreational. The development of the aquaculture industry changed this situation, because the fishers now realized that, in the competition for marine areas, they now had to document their use. In order to cope with the increasing number of interests that claimed stakes as sea users or resource harvesters, the fishers had to present their knowledge in the same format as applied in the planning processes where sea space is allocated, that means through digitized maps. Finally, technology also played a role in recent changes. In recent years many fishers have started to use advanced chart plotters like the OLEX, which interfaces with GPS and echo sounder devices. The plotter displays a 2D or 3D chart of the sea floor and information about surface temperatures. The chart is continuously updated when the vessel uses the echo sounder. The system makes it possible to plot with high accuracy how the gear is positioned in relation to the sea floor and to plot exact catch rates at the spot at certain dates, times and temperatures. Since all fishing gear has to be marked, it is also easy to plot the position of other peoples' fishing gear. Figure 4 depicts a 2D-OLEX screen picture, while 3D-images are also possible.

The OLEX offers a system for sharing sea floor data between users. Consequently, over time, the image of the sea floor in Norway will improve in quality and detail with

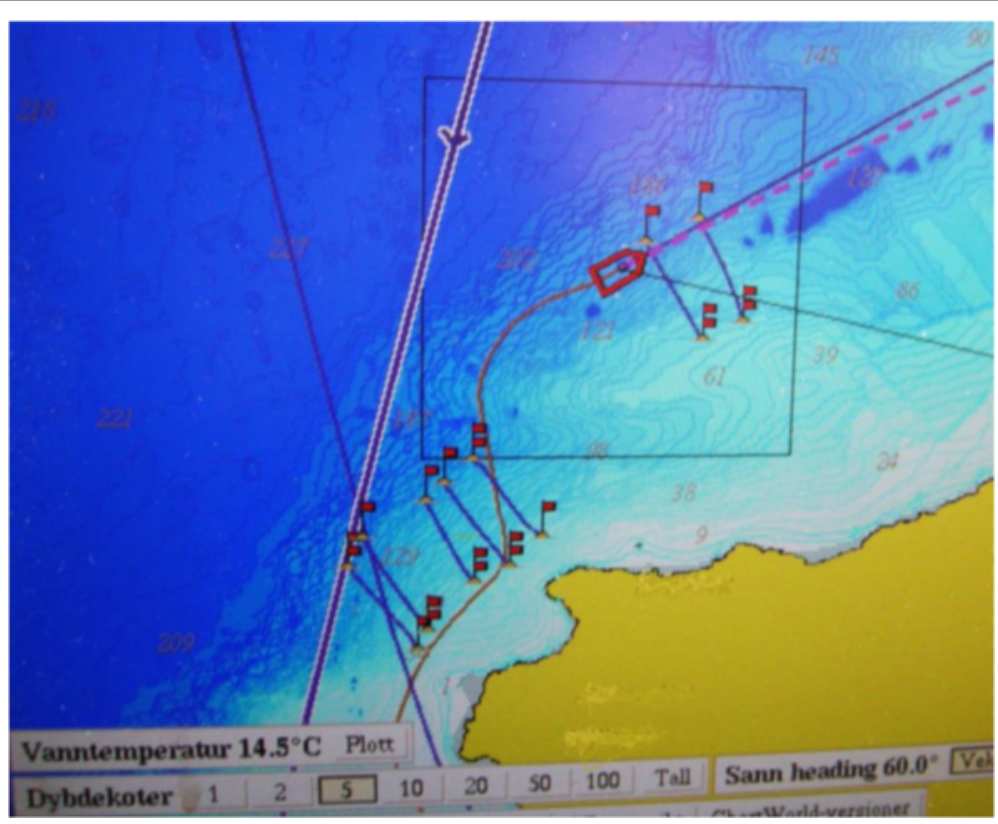

Figure 4 2D-OLEX screen picture displaying the seafloor profile, depths, deployment of gear and vessel position. Photo: Jahn Petter Johnsen. 
an increasing number of users ${ }^{j}$. In the future, this technology, in combination with a digital catch log-system will make it possible to collect fisheries data on a large scale without necessarily using interviews. Today, however, legal restrictions might limit how much data can be collected through more and more integrated systems. The OLEX- technology is an example of the dynamism of mapping. The new technology makes it easier for the fishers and other groups to produce and provide the necessary information.

Research on LEK has been concerned about the ownership of the knowledge collected (Maurstad 2002). In Norway today, DoF and IMR are "the owners" of the collected and authorised knowledge in terms of controlling the raw data and in the sense that they must be referred to when using or publishing their maps. To use the knowledge for fishing purposes is, of course, free. In some other countries, the fishers' organisations are the owners of the mapped knowledge and decide how to use it (Trouillet 2011).

As our prologue illustrates, the fishers both individually and collectively possess thorough knowledge about fish behaviour, spatial distribution and interaction with other species, but, as we have described also, their knowledge has no direct channel into the governance system. Moreover, fishers' knowledge is not only a holistic, in-depth, contextually integrated local knowledge as Berkes (2007) describes it, but it also reflects the broader technological, political and economic context in the fisheries (Johnsen et al. 2009a, 2009b; Murray et al. 2006; 2008). As Figure 4 illustrates, future possibilities for data collection and sharing increase, and new images of marine space and its inhabitants become possible. For scientific purposes, however, even the data from OLEX have to be extracted, refined and combined through translation chains before they can be used for governance purposes. Scientists and bureaucrats, in this case IMR and DoF, are controlling the authorisation and certification of the new knowledge. They represent the expertise that assures fishing knowledge validity.

Today, the fishers are heard, but only on the condition that their knowledge is translated into a format that is compatible with governance purposes and with the important reservation that it must be certified in one or two instances, that is, by DoF and IMR.

However, in relation to stock assessment it is difficult to make the claim that fishers' knowledge counts (Bjørkan 2011; Holm 2003). Even when the intentions are the best, as is the case with utilising fishers to collect data via "the reference fleet"k, Bjørkan (2011) points out that the fishers only contribute as research assistants, since their only purpose is to collect data. The participants in the reference fleet have no influence on the assessment of data or in the advisory process for the setting of quotas, which is entirely carried out by scientific experts within the framework of ICES. Fishers are not authorised as experts throughout the process. The role of an expert is not only dependent on the individual knowledge a certain person possesses but also on the fact that the person (or the institution he or she represents) is authorised by policy makers as experts in a particular subject area (Bjørkan 2011). In today's fisheries governance, the Norwegian IMR and ICES are qualified as scientific experts, while the fishers and their organisations are not awarded a similar status in relation to stock assessment. Thus, despite the obvious failures of modern fisheries science and both researchers' and managers' historical use of and sympathetic approach to fishers' knowledge, this has not resulted in destabilising the vast network established around conventional fish stock management (Johnsen 2013).

So can the process we have described just be "a play for the gallery", a kind of shadow manoeuvre to give the impression that fishers' knowledge counts? Are the Map Tools 
on DoF's homepage just a façade hiding the real knowledge? As we will describe in the last section of this paper, this is not the case. The information from DoF interviews is extracted, purified and stabilised as fishers' knowledge, and even if it is not used in model-based stock assessment, it becomes important in another frame, namely in the governance of coastal space.

\section{Outcome: the creation of coastal space as a multiple governance object}

The fisher we met in the introduction is still learning how to fish at the new fishing ground. Combining the information he can acquire from where he obtains the best catch, his experience from previous years, the information from the local fishers and the information from his echo sounder and chart plotter made him able to return to the area in 2012 and 2013 and sometimes make good catches ${ }^{1}$. He has now started to learn to know this fishing ground, which, in practical terms, means how to get fish there. He has learned something about how the fish behave in this particular underwater topography. He does not have an OLEX chart plotter; so he has to rely upon a plotter using the official charts, but if he had had an OLEX-plotter he would have been able to map the fishing ground in even more detail, which might have given him an even better understanding of the fish behaviour at this particular fishing ground. At the local scale, scientists will be able to acquire the same detailed knowledge about the particular fish behaviour only to a limited extent. However, our fisher's knowledge is qualitative and about the parts of the ecosystem he interacts with. Moreover his knowledge is purposive towards maximising his catch (Valdés-Pizzini and García-Quijano 2009; Aswani 2011). The process we have described for collection and defining of LEK is about how this knowledge is translated through specific procedures into a more formal set of spatial properties. As Degnbol (2003) points out, the scientists and fishers have knowledge of various conditions. Their scientific knowledge and LEK is not incommensurable, but can be complement to scientific knowledge on the local scale, in particular when quantitative data are lacking (Espinoza-Tenorio et al. 2013). Fisheries scientists deal with fish populations on a large scale, such as cod in the Barents Sea, while fishing knowledge often focuses on fish occurrence and behaviour on a much smaller scale, for example, on a particular fishing ground. Moreover, the scientists work on the basis of models, while the fishers learn through their relations with living nature. It is now well documented that the fishers possess substantial knowledge not only about fish behaviour (spawning and breeding areas), but also about the fishers' behaviour (good fishing grounds for different types of equipment) (Berkes 2007; Davis and Wagner 2003; Murray et al. 2006, 2008). Consequently, while the scientists collect information that adds new properties to the modelled and constructed fish stock as a governance object, the fishers' knowledge is central for the creation of the "marine space", "sea space" and "seascape" as governance objects, hereafter called "coastal space".

The Norwegian coast is a resource for food and commodity production, recreation area, input in aquaculture production, fairway, dump, natural symbol, site of beautiful views, ports and much more. When these activities are mapped, they give identity to the coastal space. So far the governance of the coast has been carried out in the form of area management and based on terrestrial management techniques. Thus, focus has been on surface activities. The fishers' knowledge, however, makes knowledge about the sea floor and the water column relevant, and while activities may share the sea surface 
without problems, the situation may be different if the sea floor and the water column were included. Trawling, for example, leaves few traces on the surface, while it may have a significant impact on the sea floor.

The land-based techniques for governing the sea as a two-dimensional space that can be divided into zones where different activities take place is therefore not sufficient for marine governance. The 2-D area as a governance object is too limited. As our prologue and our empirical examples illustrate, users like the fishers have knowledge about the third dimension, namely what is beyond the surface, the fish and their behaviour, underwater topography and, to some extent, water currents. Therefore, for the fishers, the sea is more than an area; it is a three-dimensional space. It should now be obvious, that the translation process we have described above is about how a network of actors DoF, IMR and the fishers - through the help of specific instruments, like the concept of knowledge, manuals for data sampling, charts and GIS-tools, contributes to the creation of coastal space and imbues this object with formerly unknown properties. Through coordination, distribution and inclusion, coastal space as a "multiple object" with many features, characteristics and simultaneous meanings has emerged (Mol 2002). This coastal space can be described on the basis of the mapping of features, properties and meanings as robust or vulnerable, as available or unavailable; it may represent a site of specific value (natural, social, cultural) or be defined as an opportunity for new business development. The definitions will depend on how the space is defined or more precisely, depending on who receives approval for their definition of this particular space. But defining the space it not enough. To become a governance object (parallel to Mol's described disease), a frame of reference that can assemble the multiplicity of properties into an object is also required. It is when activities are framed and coordinated by an institutionalised process like mapping that coastal space is created as a governance object. This diverse production of coastal space involves, as we have described, many players, and all have a legitimate right to participate. The multiplicity has no end, and the potential for conflict can be formidable, but the framing serves to keep the actors in place.

\section{LEK - a constituent of and constituted by coastal space}

As we have pointed out earlier, governance is about creating manageable objects (Johnsen 2013; Johnsen et al. 2009a). Research on LEK took its point of departure from the local governance of specific resources, defined and exploited inside a certain practical network and framing, and initially aiming for a contribution to scientifically constructed governance objects on this basis. It seems that the problem of shifting between different frames of reference (the practical and the abstract) was ignored (Berkes 2007; Levi-Strauss 1994). On the one hand, particularly in North Atlantic fisheries governance, the institutionalised procedures of stock assessment and advice required quantitative stock-specific data and not qualitative spatial data. On the other hand, the growing interest in and research on LEK made it difficult for the governance system to continue to neglect the existence of local stocks that science had also discovered. LEK research has thereby contributed to making fish stocks as governance objects more complex. From a governance point of view, this complexity is problematic, because it deconstructs the theoretical stock as a unity that represents nature. By documenting more empirical complexity than the theoretical models take into account, the governance object is deconstructed. Thus, the LEK research in this sense has removed properties from the governance object, made the 
abstract models less "objective", and has contributed to rendering governance on the basis of the models more difficult and less powerful.

On the other hand, LEK contributes to creating coastal space that becomes more and more complex and multiple by adding new properties. These properties are not found after a process of data mining but the result of interpretation of information collected through practical experience. In addition, LEK will also contain information about the human interaction with the ecosystem, which is essential in the move towards an ecosystem approach to fisheries management. Through the process we have described, LEK contributes to a change from a two-dimensional governance object area to a threedimensional space. As opposed to the fish stock, where diversification breaks up the fundamental conceptualisation for the models and contributes to deconstructing the governance object, coastal space becomes a more robust governance object when properties are added, because the properties are added within the same frame; that is, they can be plotted on maps and as such be bounded within the framework of area and space. As such they become independent objects that co-exist with each other and the space, but also in relation to and included in each other. They are in fact co-produced in the process described. A local fish stock is a spatial property that becomes a constituent of coastal space as a governance object, but it also becomes constituted as "local" through its relation to the constituted coastal space and all the other components in this space.

Through the procedures that produce and authorise LEK, spatial properties and the space that define them are partly defined, produced and related to each other. New technology makes it possible to continue adding new properties. This is further enhanced by the fact that maps produced through the processes are used as foundation for other maps, such as municipality plan maps with clear legal consequences for decision makers. Therefore, our final conclusion is that the application of LEK requires a different approach to governance than the one that dominates in the large-scale commercial North Atlantic fisheries.

While the numeric model-based assessment and governance will continue to be the dominant governance approach in commercial large-scale fisheries targeting single species, we see new and more empirical and experience-based governance systems evolving in nearshore fisheries. In this process, where the concept of ecosystem-based approaches to fisheries governance (EAF) is under construction, with marine spatial planning as one way of implementing EAF, we see that the role of the users may become more prominent. Not only as data collectors, but with the new mapping technologies, the fishers are, as Crampton and Krygier (2005) and Crampton (2009) pointed out, performing and making new reality, because new tools actually integrate the scientific and the practical world in new ways. Such integration may have an impact on what kind of knowledge will be used in coastal governance in the future and may influence the future division of labour between managers, politicians and stakeholders. Moreover, the widespread individual mapping processes may contribute to creating a stronger and more explicit spatial understanding of reality with implications for the images, models and concepts that are fundamental in coastal governance. This move is partly a result of LEK research and application, and it implies that LEK research along these lines will become more important in the future.

With the spatial turn in ocean and coastal governance, LEK becomes important and also represents an opportunity for increased empowerment of the users. So while LEK did not succeed as an alternative to traditional single fish stock management, it has made a comeback through coastal zone management, underlining our main perspective; 
that framing is essential. In order to understand the picture, you have to look at the frame (work)!

\section{Endnotes}

${ }^{\mathrm{a}}$ Cod in this paper refers to Northeast Arctic cod (Gadus morhua).

${ }^{\mathrm{b}}$ The practices onboard were documented through photographs, field notes and video clips.

"We prefer to use "fisher" instead of fisherman or fish harvester. Fisher is also a direct translation of the Norwegian word "fisker".

${ }^{\mathrm{d}}$ To simplify the terminology, in this article we will use the concept Local Ecological Knowledge (LEK).

${ }^{\mathrm{e}}$ This section is also based on interviews with responsible officers at the Directorate of Fisheries.

${ }^{\mathrm{f}}$ NCFA did not have a local branch in Alta, and the local "Fjord Fishers' Association" and the Sami fishers' organisation, Bivdi, were not yet established.

${ }^{g}$ Only four out of around 100 registered fishers in Alta participated in the mapping. Many of the registered fishers fish outside of Alta and do not have the targeted local knowledge.

${ }^{\mathrm{h}}$ See Figure 1. Kvænangen is the fjord system southwest of Alta in Figure 1. Alta where we have done fieldwork is not yet surveyed by IMR.

iA fishing meid or meith ("med" in Norwegian) is a cross bearing between two or more prominent landmarks that give a quite accurate positioning of the gear. The Shetland Dictionary (Graham 1984 [1979]).

j(http://www.olex.no/index_e.html)

${ }^{\mathrm{k}}$ The reference fleet is a group of fishing vessels of different sizes that fish with different gear hired by IMR to collect data under their ordinary fishing operations.

${ }^{1}$ Information given by himself on SMS, information from the DoF's quota and catch database and interviews during fieldwork in 2013.

Competing interests

The authors declare that they have no competing interests.

\section{Authors' contributions}

JPJ had the idea to the article, drafted the article and carried out the fieldwork on the fishing boat. All the three authors have carried out interviews and studied and analysed documents. BH and AMS reviewed the first draft and the article got its final form in discussions between the three authors. As first author JPJ coordinated the input from the other authors and made the revision of the peer reviewed draft. All authors are responsible for analysis and conclusions. The order of the authors reflects the responsibility and amount of work invested in the article. All authors read and approved the final manuscript.

Received: 22 April 2013 Accepted: 5 October 2013

Published: 6 February 2014

References

Aswani, S. 2011. Socioecological approaches for combining ecosystem-based and customary management in Oceania. Journal of Marine Biology. doi:10.1155/2011/845385.

Berkes, F. 2007. Sacred Ecology. New York: Routledge, Taylor and Francis Group.

Bjørkan, M. 2011. Fishing for advice: the case of the Norwegian Reference Fleet, PhD-thesis. Tromsø: University of Tromsø, Faculty of Biosciences, Fisheries and Economics, Norwegian College of Fisheries Science.

Brattland, C, and S Nilsen. 2011. Reclaiming indigenous seascapes. Sami place names in Norwegian sea charts. Polar Geography 34(4): 275-297. doi: 10.1080/1088937x.2011.644871.

Callon, M. 1986. Some elements of a sociology of translation: Domestication of the scallop and the fishermen of Saint Brieuc Bay. In Action and Belief, ed. J Law, 196-233. London: Routledge and Kegan Paul.

Callon, M, and B Latour. 1981. Unscrewing the big Leviathan: how actors macrostructure reality and how sociologists help them do so. In Advances in Social Theory and Methodology: Toward an integration of Micro and Macro Sociologies, ed. K Knorr-Cetina and AV Cicourel, 277-303. Boston: Routledge and Kegan Paul.

Crampton, JW. 2009. Cartography: performative, participatory, political. Progress in Human Geography 33(6): 840-848. doi:10.1177/0309132508105000.

Crampton, JW, and J Krygier. 2005. An introduction to critical cartography. ACME 4(1): 11-33. 
Davis, A, and JR Wagner. 2003. Who Knows? On the importance of identifying "experts" when researching local ecological knowledge. Human Ecology 31(3): 463-489.

Degnbol, P. 2003. Science and the user perspective: The gap co-management must address. In The Fisheries Co-management Experience: Accomplishments, Challenges and Prospects, ed. DC Wilson, JR Nielsen, and P Degnbol. Dordrecht: Kluwer Academic Publishers.

Directorate for Nature Management. 2007. Kartlegging av marint biologisk mangfold. (Manual for mapping of biodiversity) DN-håndbok 21-2001. Revidert 2007. Trondheim: Directorate for Nature Management.

Directorate of Fisheries. 2008. Retningslinjer for innsamling, registrering, verdivurdering og offentliggjoring av fiskeridata. Anbefalinger fra utvalget for kystnære fiskeridata. Rapport lager til internt bruk i Fiskeridirektoratet. (Proposal for a manual for collection of fisheries data). Bergen: Directorate of Fisheries.

Directorate of Fisheries. 2010a. Veiledning for innsamling av kystnære fiskeridata. Utarbeidet av arbeidsgruppen For oppfølging av utvalget for kystnære fiskeridata (Manual for collection of fisheries data). Bergen: Directorate of Fisheries.

Directorate of Fisheries. 2010b. Veiledning i intervjuteknikk ved registrering av kystnære fiskeridata. Vedlegg til veiledning for innsamling av kystnære fiskeridata (Appendix to manual, guidelines for how to conduct interviews). Bergen: Directorate of Fisheries.

Espeland, SH, J Albretsen, G Dahle, L Asplin, T Olsen, EM Olsen, JH Simonsen, and T Bodvin. 2010. Metode for lokalisering og verdisetting av gyteplasser i fjorder med dype terskler, åpne havbukter og sund (Methodology for localisation and valueing of spawning grounds. Fisken og Havet Særnummer (1). Bergen, Institute of Marine Research

Espinoza-Tenorio, A, M Wolff, I Espejel, and G Montaño-Moctezuma. 2013. Using traditional ecological knowledge to improve holistic fisheries management: Transdisciplinary modeling of a lagoon ecosystem of southern Mexico. Ecology and Society 18(2). doi: 10.5751/es-05369-180206.

Finlayson, AC. 1994. Fishing for truth. A sociological analysis of northern cod stock assessments 1977-1990. St. John's: ISER.

Garcia, SM, and AT Charles. 2007. Fishery systems and linkages: from clockworks to soft watches. ICES Journal of Marine Science: Journal du Conseil 64(4): 580-587. doi: 10.1093/icesjms/fsm013.

Graham, JJ. 1984. The Shetland Dictionary. Lerwick: Shetland Publishing Company. 1979.

Hersoug, B. 2005. Closing the Commons. Norwegian fisheries from open acess to private property. Eburon: Delft.

Holm, P. 1995. The dynamics of institutionalization: transformation processes in Norwegian fisheries. Administrative Science Quarterly 40(3): 398-422.

Holm, P. 2003. Crossing the border: on the relationship between science and fishermen's knowledge in a resource management context. MAST (Maritime Studies) 2(1): 5-33.

Holm, P, and KN Nielsen. 2007. Framing fish, making markets: the construction of Individual Transferable Quotas (ITQs). In Michel Callon, Yuval Millo, and Fabian Muniesa, ed. M Devices, 173-195. Oxford: Blackwell Publishing.

Holm, P, B Hersoug, and SA Raanes. 2000. Revisiting Lofoten: co-managing fish stocks or fishing space? Human Organizaton 59(3): 353-364.

ICES. 2010. ECOREGION Barents Sea SUBJECT Request by the Norwegian ministry of fisheries and coastal affairs: Evaluation of a rebuilding plan for coastal cod. In ICES Advice 2010 Book 3. Kopenhagen: International Council of the Exploration of the Sea.

Jentoft, S, and T Kristoffersen. 1989. Fishermen's co-management: the case of the Lofoten fishery. Human Organization 84(4): 355-365

Johannes, RE, MMR Freeman, and RJ Hamilton. 2000. Ignore fishers' knowledge and miss the boat. Fish and Fisheries 1(3): 257-271. doi:10.1111/j.1467-2979.2000.00019.x.

Johnsen, JP. 2004. Latour, natur og havforskere - hvordan produsere natur? Sosiologi I Dag 34(2): 47-67.

Johnsen, JP. 2013. Is fisheries governance possible? Governability and Governmentality in Norwegian fisheries. Fish and Fisheries. doi:10.1111/faf.12024 (in press).

Johnsen, JP, P Holm, PS Sinclair, and D Bavington. 2009a. The cyborgization of the fisheries. On attempts to make fisheries management possible. Mast 7(2): 9-34.

Johnsen, JP, G Murray, and B Neis. 2009b. North Atlantic fisheries in change - from organic associations to cybernetic organizations. Mast 9(2): 55-82.

Knutsen, JA, H Knutsen, E Rinde, C Hartvig, T Bodvin, and E Dahl. 2010. Mapping biological resources in the coastal zone: an evaluation of methods in a pioneering study from Norway. AMBIO 39(2): 148-158.

Latour, B. 2005. Reassembling the social an introduction to actor-network-theory, Clarendon lectures in management studies. Oxford: Oxford University Press.

Levi-Strauss, C. 1994. Den vilde tanke (The Savage Mind) Danish edition. København: Gyldendal.

Maurstad, A. 1997. Sjarkfiske og ressursforvaltning. Tromsø: Doktoravhandling, Universitetet i Tromsø.

Maurstad, A. 2000. Trapped in biology: An interdisciplinary attempt to integrate fish harvesters' knowledge into Norwegian fisheries management. In Finding our Sealegs. Linking Fishery People and Their Knowledge with Science and Mangement, ed. B Neis and L Felt, 135-152. St. John's, Newfoundland: Iser.

Maurstad, A. 2002. Fishing in murky waters-ethics and politics of research on fisher knowledge. Marine Policy 26(3): 159-166. doi:10.1016/s0308-597x(01)00045-8.

Maurstad, A, and JH Sundet. 1998. Den usynlige torsken - Forsker- og fiskerkunnskap om lokale fiskeressurser (The invisible cod - scientist and fishermen's knowledge about local fish resources). In Fjordressurser og reguleringspolitikk. En utfordring for kystkommuner? ed. BK Sagdahl. Oslo: Kommuneforlaget.

McGoodwin, JR. 1990. Crisis in the World's Fisheries People, Problems, and Policies. Stanford: Stanford University Press.

Mol, A. 2002. The Body Multiple: Ontology in Medical Practice. Durham: Duke University Press.

Murray, G, B Neis, and J Johnsen. 2006. Lessons learned from reconstructing interactions between local ecological knowledge, fisheries science, and fisheries management in the commercial fisheries of Newfoundland and Labrador, Canada. Human Ecology 34(4): 549-571.

Murray, G, Neis, B, Palmer C, and Schneider D. 2008. Mapping cod: fisheries science, fish harvesters' ecological knowledge and cod migrations in the northern Gulf of St. Lawrence. Human Ecology 36(4): 581-598. doi:10.1007/s10745-008-9178-1.

Neis, B, and Felt L. 2000. Finding our sea legs: Linking fishery people and their knowledge with science and management. St. John's, Newfoundland: Institute of Social and Economic Research. 
Neis, B, Felt LF, R Haedrich, and D Schneider. 1999. An interdiscplinary method for collecting and integrating fishers' ecological knowledge into resource mangement. In Fishing Places, Fishing People. Traditions and Issues in Canadian Small-Scale Fisheries, ed. D Newell and R Omner, 217-238. Toronto: University of Toronto Press.

Nielsen, KN. 2008. Boundary Construction in Mandated Science the Case of Ices' Advice on Fisheries Management. Tromsø: University of Tromsø, Norwegian College of Fishery Science, Department of Social Science and Marketing.

Palmer, C, and R Wadley. 2007. Local environmental knowledge, talk, and skepticism: using 'LES' to distinguish 'LEK' from 'LET' in Newfoundland. Human Ecology 35(6): 749-760. doi:10.1007/s10745-006-9108-z.

Rollefsen, G. 1933. The otoliths of the cod: preliminary report, Fiskeridirektoratets skrifter, Serie Havundersøkelser, vol. 4 , no 3. Bergen: Fiskeridirektoratet.

Rozwadowski, HM. 2002. The sea knows no boundaries: a century of marine science under ICES. Seattle: ICES, University of Washington Press.

Schwach, V. 2000. Havet, fisken og vitenskapen: fra fiskeriundersøkelser til havforskningsinstitutt 1860-2000. Bergen: Havforskningsinstituttet/Institute for Marine Research.

Smith, G. 2011. Maps, networks and a sea that won't conform: thinking critically about marine spatial planning in Scotland. Edinburgh, Scotland: University of Edinburgh.

Smith, G, and RE Brennan. 2012. Losing our way with mapping: thinking critically about marine spatial planning in Scotland. Ocean \& Coastal Management 69: 210-216. http://dx.doi.org/10.1016/j.ocecoaman.2012.08.016.

Søreng, SU. 2006. Moral discourse in fisheries co-management: a case study of the Senja fishery, northern Norway. Ocean \& Coastal Management 49(3-4): 147-163. http://dx.doi.org/10.1016/.ocecoaman.2006.02.008.

St. Martin, K, and M Hall-Arber. 2008. Creating a place for "community" in New England Fisheries. Human Ecology Review 15(2): 161-170.

Thornton, TF, and AM Scheer. 2012. Collaborative engagement of local and traditional knowledge and science in marine environments: A Review. Ecology and Society 17(3): 8. doi:10.5751/es-04714-170308.

Trouillet, B. 2011. Mapping human activities at sea: an input for Marine Spatial Planning, French examples, Paper presented at the MARE Amsterdam.

Valdés-Pizzini, M, and C García-Quijano. 2009. Coupling of humans, habitats and other species: a study of the fishers' traditional ecological knowledge (TEK) in La Parguera. Caribbean Journal of Science 45(2-3): 363-371.

Valdés-Pizzini, M, CG García-Quijano, and MT Schärer-Umpierre. 2012. Connecting humans and ecosystems in tropical fisheries: social sciences and the ecosystem-based fisheries management in Puerto Rico and the Caribbean. Caribbean Studies 40(2): 95-128.

doi:10.1186/2212-9790-13-2

Cite this article as: Johnsen et al: The creation of coastal space - how local ecological knowledge becomes relevant. Maritime Studies 2014 13:2.

Submit your manuscript to a SpringerOpen ${ }^{\circ}$ journal and benefit from:

- Convenient online submission

- Rigorous peer review

- Immediate publication on acceptance

- Open access: articles freely available online

- High visibility within the field

- Retaining the copyright to your article

Submit your next manuscript at $\boldsymbol{\nabla}$ springeropen.com 